\title{
Resistance of Brazilian wheat cultivars to blast under controlled condition
}

\author{
João Leodato Nunes Maciel ${ }^{*}$ (1) Gustavo Bilíbio dos Santos ${ }^{2}$ (i) Carlos Augusto Pizolotto $^{3}$ \\ Marcos Kovaleski ${ }^{3}$ (D) Alieze Nascimento da Silva ${ }^{4}$ Carolina Cardoso Deuner ${ }^{3}$ \\ Ivan Francisco Dressler da Costa ${ }^{4}$
}

${ }^{1}$ Embrapa Trigo, 99050-970, Passo Fundo, RS, Brasil. E-mail: joao.nunes-maciel@embrapa.br. "Corresponding author. ${ }^{2}$ Faculdade de Agronomia e Medicina Veterinária, Universidade de Passo Fundo (UPF), Passo Fundo, RS, Brasil.

${ }^{3}$ Programa de Pós-graduação em Agronomia, Universidade de Passo Fundo (UPF), Passo Fundo, RS, Brasil. ${ }^{4}$ Programa de Pós-graduação em Agronomia, Universidade Federal de Santa Maria (UFSM), Santa Maria, RS, Brasil.

\begin{abstract}
The first report of wheat blast in the world was in Brazil, in 1986. Since then, a great effort has been made towards the development of wheat cultivars resistant to this disease, which is caused by the fungus Pyricularia oryzae Triticum (PoT). The objective of this research was to ( $i$ ) evaluate the resistance of wheat genotypes to blast and (ii) verify the correlation between disease severity on wheat spikes and sporulation rate of PoT on spike rachises. Plants of 40 cultivars grown in pots, at the flowering stage (stage 65 on the Zadoks scale), were inoculated with a suspension of conidia of a PoT isolate representative of the main variant of the fungus reported in Brazil. Severity of blast on the spikes at 5 and 7 days after inoculation (dai) and the rate of sporulation of the fungus on the rachis (conidia per $g$ of rachis) were evaluated. Eighty percent of the cultivars that were classified in the group with the lowest sporulation rate were also classified in the group with the highest resistance at 7 dai. However, the correlation coefficients of the analysis established between the cultivar severity at 5 and 7 dai averages and the PoT sporulation rate averages were not significant $(r=0.2464$ and $r=0.2047$, respectively). Results obtained represent the updated characterization to blast of wheat cultivars in Brazil and constitute an important exploratory framework for the evaluation of the reaction of wheat genotypes based on the sporulation rate of PoT on their tissues.
\end{abstract}

Key words: Pyricularia oryzae Triticum, severity, sporulation.

Resistência de cultivares brasileiras de trigo à brusone sob condições controladas

RESUMO: O primeiro relato da brusone do trigo no mundo foi no Brasil, em 1986. Desde então, tem-se realizado um esforço muito grande com vistas ao desenvolvimento de cultivares de trigo resistentes a esta doença, a qual é causada pelo fungo Pyricularia oryzae Triticum (PoT). O objetivo deste trabalho foi de (i) avaliar a resistência de genótipos de trigo à brusone e (ii) verificar a correlação entre severidade da doença em espigas e taxa de esporulação de PoT em ráquis de espigas. Plantas de 40 cultivares brasileiras de trigo crescidas em vasos, no estádio de florescimento (estádio 65 da escala de Zadoks), foram submetidas à inoculação com uma suspensão de conídios de um isolado de PoT representativo da principal variante do fungo encontrada no Brasil. A severidade de brusone nas espigas aos cinco e sete dias após a inoculação (dai) e a taxa de esporulação do fungo nas ráquis (conídios por g de ráquis) foram avaliadas. Oitenta por cento das cultivares que foram classificadas no grupo com menor taxa de esporulação também foram classificadas no grupo de maior resistência aos sete dai. Entretanto, os coeficientes de correlação da análise estabelecida entre as médias de severidade das cultivares aos cinco e sete dai e as médias da taxa de esporulação de PoT não foram significativos ( $r=0,2464$ e $r=0,2047$, respectivamente). Os resultados obtidos representam a caracterização atualizada da reação à brusone de cultivares de trigo do Brasil e constituem-se em importante marco exploratório da avaliação da reação de genótipos de trigo baseado na taxa de esporulação de PoT em seus tecidos.

Palavras-chave: Pyricularia oryzae patotipo Triticum, severidade, esporulação.

\section{INTRODUCTION}

Blast, as it is known in many different crops, is caused by the fungus Pyricularia oryzae Cavara 1892 (synonym to Magnaporthe oryzae (Catt.) B.C. Couch 2002) (COUCH \& KOHN, 2002; ZHANG et al., 2016). Wheat blast is caused by a subpopulation within $P$. oryzae, the $P$. oryzae Triticum pathotype (PoT). Wheat blast is one of the main diseases that restricts Brazil's interests in achieving self-sufficiency in wheat production (GOULART et al., 2007) causing damage of up to $100 \%$ in Brazilian wheat fields (MACIEL et al., 2020). In South America, blast is also a major threat 
to wheat production with potential of affecting more than three million hectares of wheat fields in the continent (KOHLI et al., 2011). In February of 2016, wheat blast was first identified outside the South American continent, in Asia, with reports of serious epidemics of the disease in wheat fields of Bangladesh (CALLAWAY, 2016). More recently, its occurrence was reported in Zambia, Africa (TEMBO et al., 2020).

Adoption of resistant wheat cultivars to blast is included as part of the integrated management of the disease in Brazil (MACIEL et al., 2014). Although some important advances have already been achieved in relation to the genetic resistance to wheat blast, this strategy faces limitations due to the absence of cultivars with a high level of resistance to the disease. The cultivar BR18-Terena, which became available to growers in the mid-1980s, is still adopted by many growers in Brazil due to its high basal resistance to blast demonstrated under field epidemics, in addition to producing grains of high quality. Besides, wheat cultivars available commercially more recently have a significant level of resistance to the disease, highlighting the followings: BRS 404, ORS 1401, ORS 1403, TBIO Sonic, TBIO Mestre, TBIO Sossego, and CD 116 (MACIEL et al., 2020).

The development of wheat blast in the fields depends on several environmental factors, highlighting humidity and temperature as fundamental in determining the limit of damage that the disease can cause (KOVALESKI et al, 2019). Environmental factors also influence the variability of the pathogen in a magnitude that is difficult even to speculate. In this sense and regarding that PoT is present in all Brazilian wheat agroecosystems (DUVEILLER et al., 2010; MACIEL et al., 2014; CASTROAGÚDIN et al., 2016), it is probable that both incidence and severity of blast are dependent on the fungal variant prevalent in that agroecosystem. This scenario is an indication that the PoT variability should be considered by the Brazilian wheat breeding programs, making it recommendable that genotypes generated by these programs be evaluated in relation to the reaction of the prevalent races of the pathogen in Brazil (CRUZ et al., 2010). DANELLI (2015) evaluated 144 Brazilian PoT isolates according their aggressiveness based on the reaction of seedlings and detached spikes of wheat and barley genotypes submitted to inoculation with spore suspensions of these isolates, grouping them into 17 and 4 races, respectively. This evaluation conducted by DANELLI (2015) was very important because represents quite well the variability of PoT in Brazil.
Assessment of resistance to blast on wheat spikes has been traditionally performed by estimating the percentage of area affected by the disease on the spikes (MACIEL et al., 2013a). This method allowed assessing disease development at different time points following the infection. Its problem is the fact that is a semi-quantitative method and the score may vary depending on the observer. Although, it is more demanding in terms of actions and equipment, the processing of digital images greatly minimizes the limitations based on the visual estimation of the severity of the disease in symptomatic segments of plants (MACIEL et al., 2013b). Conversely, an alternative to avoid evaluation errors based on visual estimation is to use quantitative measures such as the comparison between genotypes according to the rate of sporulation of the pathogen as an infective agent of the host plant. Strategies like these have been carried out, for example, to assess resistance to Phakopsora pachyrhizi on soybean (VITTAL et al., 2014) and Phytophthora infestans on potato (LECLERC et al., 2019).

The objective of this research was to (i) evaluate the resistance of wheat genotypes to blast and (ii) to verify the correlation between disease severity on wheat spikes and PoT sporulation rate on the spike rachises.

\section{MATERIALS AND METHODS}

The research was carried out in 2018 at Embrapa Trigo, Passo Fundo, RS, Brazil. In each of the three experiments carried out, two pots with plants from each one of the 40 wheat cultivars were used to assess the severity of blast on the spikes and the rate of sporulation of PoT on the rachises of these spikes.

\section{Production of plants for inoculation}

The plants used in the experiments were conducted in $8 \mathrm{~L}$ plastic pots containing soil corrected for agricultural purposes according to chemical analysis. The pots with the plants remained in greenhouse environment until the inoculation timing, with temperatures and relative humidity ranging from 14 to $27{ }^{\circ} \mathrm{C}$ and from 40 to $60 \%$, respectively. The covering fertilization of the plants was carried out by the application of a solution of $100 \mathrm{~g}$ of urea $(45.5 \%$ N) / 20 L of water, being irrigated on the pots in three distinct stages of the development of the plants (third, fifth, and seventh true leaf expanded). Ten seeds were sown in each pot, but only five plants were left until they were used in the inoculation procedures. The plants were cultivated until flowering, stage 65 on 
the scale of ZADOKS et al. (1974), when they were submitted to inoculation.

\section{Inoculum obtention, preparation and inoculation}

The isolate of PoT used in the inoculation procedures was the $P y$ 12.1.209, which belongs to the collection of PoT isolates from Embrapa Trigo and is preserved at $-18{ }^{\circ} \mathrm{C}$ on filter paper. This isolate was classified by DANELLI (2015) as being of the races A1 and A1' according to responses on seedlings and detached spikes, respectively. It is noteworthy that these two racial patterns are distinct and are based on the reaction of the same differentiating cultivars, but at different stages of development. According to the study conducted by DANELLI (2015), the two races, A1 and A1', are prevalent in Brazil.

For the inoculation, the monosporic PoT isolate kept on filter paper was transferred to Petri dishes with oat-agar culture medium (oatmeal flour, $60 \mathrm{~g} \mathrm{~L}^{-1}$ ) (TUITE, 1969), and incubated for 7 to 9 days under photoperiod of $12 \mathrm{~h}$ at $25 \pm 2{ }^{\circ} \mathrm{C}$. From the matrix colony grown, the fungus mycelium was transferred to Petri dishes with oat-agar culture medium, which were incubated at the same conditions described above for 10 to 12 days. To prepare the inoculum, the Petri dishes were flooded with distilled water plus a Tween $80^{\circledR}$ adhesive spreader $(0.01 \%)$. With the help of a brush or glass slide, the plates were scraped, in order to dislodge the conidia. The scraped material from the Petri dishes was filtered through a sieve with gauze inside. The spores count was done in a Neubauer Chamber (Loptik Labor $0.0025 \mathrm{~mm}^{2}$ ) with the aid of a stereomicroscope, $400 \times$ magnification, and the conidia concentration was adjusted to $10^{5}$ conidia $\mathrm{mL}^{-1}$.

The conidia suspension was applied to the plants using a $500 \mathrm{~mL}$ plastic spray bottle. The target on the spraying of the conidial suspension was the spikes, which received it until the liquid drainage started. After inoculation, the plants were individually covered with a plastic bag and kept in a controlled environment chamber, where they remained for $24 \mathrm{~h}$ in the dark, at $24-25{ }^{\circ} \mathrm{C}$ and relative humidity $(\mathrm{RH})>$ $90 \%$. After $24 \mathrm{~h}$, the plastic bags were removed and the plants kept for 14 days, at $24-25{ }^{\circ} \mathrm{C}$, under photoperiod of $12 \mathrm{~h}$ and RH between 60 and $70 \%$.

\section{Evaluations}

Based on the scale established by MACIEL et al. (2013a), the assessments of spike blast severity were performed by means of visual estimation of the symptomatic area of each spike 5 and 7 days after inoculation (dai). The number of spikes evaluated in each pot ranged from 5 to 20. After the evaluation on the spikes, the plants in the pots remained in the environment described above for 14 days. After this period, the spikes were collected, separated, put inside paper bags and kept at $-20{ }^{\circ} \mathrm{C}$ until their spikelets were manually removed, leaving just the rachis. From each one of the three experiments conducted and from each cultivar, two groups of seven rachises from each cultivar were randomly separated, and evaluated according to sporulative capacity of PoT. Each group of these seven rachises was weighed and, after asepsis in commercial sodium hypochlorite $(2.5 \%)$ in the proportion of $1: 1$ (water: commercial sodium hypochlorite) for $1 \mathrm{~min}$, tworinsed with distilled and sterilized water. Then, they were placed in plastic Petri dishes $(15 \mathrm{~mm}$ high $\times$ $86 \mathrm{~mm}$ in diameter) containing inside blotting paper previously moistened. For sporulation of PoT, the Petri dishes were transferred to a growth chamber with photoperiod of $12 \mathrm{~h}$ for $96 \mathrm{~h}$ at $25 \pm 2{ }^{\circ} \mathrm{C}$. After that period, the rachises were removed from the Petri dishes and placed in a Falcon tube $(15 \mathrm{~mL})$ with 5 $\mathrm{mL}$ of sterile distilled water. Each tube was shaken on a MA 162 tube shaker $\left(\right.$ Marcon $\left.^{\circledR}\right)$ for $40 \mathrm{~s}$. After stirring, an aliquot of the solution was removed and the number of conidia per $\mathrm{mL}$ was counted in Neubauer chambers (Loptik Labor $0.0025 \mathrm{~mm}^{2}$ ) with the aid of a stereomicroscope under $400 \times$ magnification. Two counts were done per tube, totaling six counts per wheat cultivar, two per sowing date. The number of conidia counted was converted to number of conidia per $\mathrm{g}$ of rachis.

\section{Statistical analysis}

Each one of the three experiments conducted in the research was carried out under completely randomized experimental design. The results obtained in the experiments were compiled and subjected to analysis of variance (ANOVA) and the means compared to each other using the Scott \& Knott statistical test $(\mathrm{P}<0.05)$. The ANOVA and the comparison of means of the three variables considered in the study (severity of blast on the spikes at 5 and 7 dai, and sporulation rate (conidia per $\mathrm{g}$ of rachis)) were conducted with the original data transformed to square-root of $x+10$. The mean of the evaluation scores of each pot in relation severity of blast on the spikes at 5 and 7 dai, was considered as experimental data in the statistical analyzes. All statistical analyzes were performed with the support of the Genes program, version 1990.2018.71 (CRUZ, 2001). The mean obtained for each cultivar were used to determine the correlation coefficient between the variables evaluated 
using the Microsoft Excel (Microsoft corporation, Seattle, USA). The software Microsoft Excel was also used to build the boxplots graphics.

\section{RESULTS}

Based on Scott-Knott statistical test, the 40 cultivars were separated into two groups according to the degree of severity of blast on the spikes as at 5 dai as at 7 dai (Table 1). At 5 dai, the most resistant group was formed by 34 cultivars, with severity ranging from 0.5 to $4.4 \%$. The other cultivars (6) were classified in a second group, of greater susceptibility, composed by the cultivars BRS Guamirim, IPR Potiporã, BRS 264, IAC 385 - Mojave, CD 108 and IPR 144 , and with severity ranging from 8.8 to $16.8 \%$. At 7 dai, two groups were also formed, the one with higher resistance being formed by 32 cultivars, all of which belonged to the most resistant group according the evaluation at 5 dai. The most susceptible group at 7 dai was formed by the cultivars BRS Guamirim, IPR Potiporã, BRS 264, IAC 385 - Mojave, CD 108, IPR 144, BRS Reponte and IPR Panaty, with severity ranging from 12.2 to $32.7 \%$.

Two groups of cultivars were formed according to the statistical test in relation the production of conidia per $g$ of rachis (Table 1). The group with the lowest sporulation rate was formed by 25 cultivars, with mean sporulation ranging from 3.2 $\times 10^{6}$ to $26.6 \times 10^{6}$ conidia per $g$ of rachis. The group with the highest sporulation rate was formed by 15 cultivars, which showed a sporulation rate ranging from $31.8 \times 10^{6}$ to $56.5 \times 10^{6}$ conidia per $\mathrm{g}$ of rachis.

The distribution of the results in the boxplot graphs confirmed that the data variation for the severity variables at 5 and 7 dai was quite reduced, with few outliers (Figure 1C and 1B). In these graphs, the difference between the most resistant and the most susceptible cultivars in relation to the evolution of the disease in the two evaluations is also clear. In the case of PoT sporulation on the rachises (Figure 1A), the variation of data for each cultivar is much greater, with a large number of outliers. However, the differences between the cultivars are not as clear as those observed in the variables related to the severity of blast in the spikes. What is most noteworthy is the difference between the cultivars allocated at the extremes of the graph.

Based on the data of cultivar means, it was reported that there was no statistical significance in the analysis of the correlation between the severity of the disease on the spikes and the sporulation of PoT on the rachises and with and with very low values of the correlation coefficients for the two analyzes $(\mathrm{r}=0.2464$, for severity at 5 dai $\times$ production of conidia; and, $r=0.2047$, for severity at 7 dai $\times$ production of conidia).

\section{DISCUSSION}

The findings obtained are relevant because they formed an updated classification of the reaction to blast on the spikes of 40 Brazilian wheat cultivars of very frequent use in regions of Brazil with a historic of natural occurrence of the disease. Although the Scott \& Knott test $(0.05)$ established the formation of two groups of in the analyzes made at 5 and 7 dai, the analysis of the results should not be restricted to the classification determined by the statistical test. In particular, the ranking of these cultivars should also be highlighted, with special attention to those that had very low absolute values of severity, such as, for example, the cultivars TBIO Mestre and ORS 1401.

It is also noteworthy that the results obtained regarding the ranking of the tested cultivars in relation to the blast reaction are considerably in line with the ranking of Brazilian wheat cultivars established by MACIEL et al. (2020). However, it is important to regard in this comparison the fact that the assessment made by MACIEL et al. (2020) was carried out under natural conditions of blast occurrence in field plots.

Evaluating wheat cultivars for the reaction of cultivars with a PoT isolate ( $P y$ 12.1.209), selected from the Brazilian population of the causal agent of blast in the country for its representativeness in terms of aggressiveness (races A1 and A1') (DANELLI, 2015), gives to the research a differential character. This positive observation in relation to the conduction of the research should be added to the message of appreciation and incentive to actions of monitoring the characteristics of pathogenicity and aggressiveness of phytopathogenic agents of agricultural crops of greater economic importance.

The absence of dependence between development of blast on the spikes and later production of conidia of PoT on the rachises of these spikes observed in the research should not be considered as a definitive finding that there is no connection between these two types of variables in the pathosystem wheat- PoT. It is important to emphasize that this research is the first report on the use of the sporulation rate of PoT as a criterion for evaluating and comparing the reaction of wheat cultivars to blast (Table 1) and further studies on the topic should be encouraged. In this sense, the authors of the research understand that there are actions that can improve 
Table 1 - Severity of blast on spikes and rate of sporulation of Pyricularia oryzae Triticum on spike rachises of wheat cultivars.

\begin{tabular}{|c|c|c|c|c|}
\hline \multirow[t]{2}{*}{ Cultivar } & \multicolumn{2}{|c|}{---------------Severity on spikes------------ } & \multicolumn{2}{|c|}{-----Conidia x 106 per g of rachis---- } \\
\hline & 5 dai $^{1}$ & 7 dai & & \\
\hline BRS Guamirim & $16.8 \mathrm{a}^{2}$ & $32.7 \mathrm{a}$ & 39.8 & $\mathrm{a}$ \\
\hline IPR Potiporã & $9.4 \mathrm{a}$ & $23.4 \mathrm{a}$ & 13.6 & $\mathrm{~b}$ \\
\hline BRS 264 & $12.7 \mathrm{a}$ & $17.6 \mathrm{a}$ & 25.4 & $\mathrm{~b}$ \\
\hline IAC 385 - Mojave & $7.3 \mathrm{a}$ & $15.3 \mathrm{a}$ & 16.6 & $\mathrm{~b}$ \\
\hline CD 108 & $10.2 \mathrm{a}$ & $14.4 \mathrm{a}$ & 35.8 & $\mathrm{a}$ \\
\hline IPR 144 & $8.8 \mathrm{a}$ & $14.3 \mathrm{a}$ & 37.4 & $\mathrm{a}$ \\
\hline BRS Reponte & $4.4 \mathrm{~b}$ & $12.4 \mathrm{a}$ & 13.9 & $\mathrm{~b}$ \\
\hline IPR Panaty & $5.1 \mathrm{~b}$ & $12.2 \mathrm{a}$ & 24.5 & $\mathrm{~b}$ \\
\hline BRS Gralha Azul & $5.3 \mathrm{~b}$ & $11.8 \mathrm{~b}$ & 22.6 & $\mathrm{~b}$ \\
\hline CD 150 & $5.4 \mathrm{~b}$ & $10.2 \mathrm{~b}$ & 32.4 & $\mathrm{a}$ \\
\hline ORS 1403 & $0.4 \mathrm{~b}$ & $9.7 \mathrm{~b}$ & 13.8 & $\mathrm{~b}$ \\
\hline BR 18 - Terena & $4.2 \mathrm{~b}$ & $9.5 \mathrm{~b}$ & 24.6 & $\mathrm{~b}$ \\
\hline IAC 389 - Atakama & $4.7 \mathrm{~b}$ & $9.0 \mathrm{~b}$ & 20.5 & $\mathrm{~b}$ \\
\hline IAC 388 - Arpoador & $3.7 \mathrm{~b}$ & $8.2 \mathrm{~b}$ & 38.3 & $\mathrm{a}$ \\
\hline BRS 404 & $2.3 \mathrm{~b}$ & $7.8 \mathrm{~b}$ & 26.6 & $\mathrm{~b}$ \\
\hline BRS Angico & $2.3 \mathrm{~b}$ & $7.5 \mathrm{~b}$ & 56.5 & $\mathrm{a}$ \\
\hline BRS Graúna & $3.4 \mathrm{~b}$ & $7.2 \mathrm{~b}$ & 12.5 & $\mathrm{~b}$ \\
\hline CD 1440 & $3.7 \mathrm{~b}$ & $6.9 \mathrm{~b}$ & 35.2 & $\mathrm{a}$ \\
\hline CD 117 & $2.9 \mathrm{~b}$ & $6.4 \mathrm{~b}$ & 41.0 & $\mathrm{a}$ \\
\hline ORS Citrino & $2.8 \mathrm{~b}$ & $6.4 \mathrm{~b}$ & 24.1 & $\mathrm{~b}$ \\
\hline BRS 229 & $3.3 \mathrm{~b}$ & $6.3 \mathrm{~b}$ & 44.1 & $\mathrm{a}$ \\
\hline BRS Tangará & $2.7 \mathrm{~b}$ & $6.0 \mathrm{~b}$ & 37.8 & $\mathrm{a}$ \\
\hline Ametista & $2.4 \mathrm{~b}$ & $5.9 \mathrm{~b}$ & 32.4 & $\mathrm{a}$ \\
\hline CD 1595 & $2.1 \mathrm{~b}$ & $5.5 \mathrm{~b}$ & 48.5 & $\mathrm{a}$ \\
\hline BRS Pardela & $3.5 \mathrm{~b}$ & $5.5 \mathrm{~b}$ & 16.5 & $\mathrm{~b}$ \\
\hline ORS Madre Pérola & $2.4 \mathrm{~b}$ & $5.3 \mathrm{~b}$ & 32.0 & $\mathrm{a}$ \\
\hline BRS 331 & $2.1 \mathrm{~b}$ & $4.9 \mathrm{~b}$ & 22.8 & $\mathrm{~b}$ \\
\hline TBIO Sossego & $0.7 \mathrm{~b}$ & $4.6 \mathrm{~b}$ & 15.9 & $\mathrm{~b}$ \\
\hline MGS Brilhante & $1.0 \mathrm{~b}$ & $4.5 \mathrm{~b}$ & 17.8 & $\mathrm{~b}$ \\
\hline CD 1303 & $1.4 \mathrm{~b}$ & $4.1 \mathrm{~b}$ & 42.6 & $\mathrm{a}$ \\
\hline CD 1104 & $1.5 \mathrm{~b}$ & $3.4 \mathrm{~b}$ & 31.8 & $\mathrm{a}$ \\
\hline Jadeíte 11 & $1.2 \mathrm{~b}$ & $3.4 \mathrm{~b}$ & 26.5 & $\mathrm{~b}$ \\
\hline CD 1550 & $1.2 \mathrm{~b}$ & $3.1 \mathrm{~b}$ & 19.4 & $\mathrm{~b}$ \\
\hline BRS Gaivota & $1.6 \mathrm{~b}$ & $2.9 \mathrm{~b}$ & 12.3 & $\mathrm{~b}$ \\
\hline CD 116 & $1.1 \mathrm{~b}$ & $2.7 \mathrm{~b}$ & 5.3 & $\mathrm{~b}$ \\
\hline TBIO Sintonia & $0.9 \mathrm{~b}$ & $2.6 \mathrm{~b}$ & 7.0 & $\mathrm{~b}$ \\
\hline TBIO Audaz & $1.1 \mathrm{~b}$ & $2.5 \mathrm{~b}$ & 23.9 & $\mathrm{~b}$ \\
\hline TBIO Sonic & $0.7 \mathrm{~b}$ & $2.2 \mathrm{~b}$ & 3.2 & $\mathrm{~b}$ \\
\hline ORS 1401 & $0.6 \mathrm{~b}$ & $1.0 \mathrm{~b}$ & 9.9 & $\mathrm{~b}$ \\
\hline TBIO Mestre & $0.5 \mathrm{~b}$ & $0.9 \mathrm{~b}$ & 10.2 & $\mathrm{~b}$ \\
\hline Mean & 3.70 & 8.00 & 25.12 & \\
\hline Coefficient of variation $(\%)^{3}$ & 8.68 & 12.24 & 30.57 & \\
\hline
\end{tabular}

${ }^{1}$ dai, days after inoculation;

${ }^{2}$ Means followed by the same letter (vertical) do not differ statistically by the Scott $\&$ Knott test at 0.05 probability;

${ }^{3}$ Analysis of variance and the means comparison test were performed with the data transformed to the root of $x+10$.

the efficiency in the process of evaluating PoT sporulation in plant segments of wheat genotypes. In the case of rachises, an increase in the number of these segments evaluated by each genotype is suggested, a condition that must reduce the experimental error. Standardizing the spikes (from which the rachis is obtained), considering aspects such as the size and severity of blast, may also help to reduce statistical 


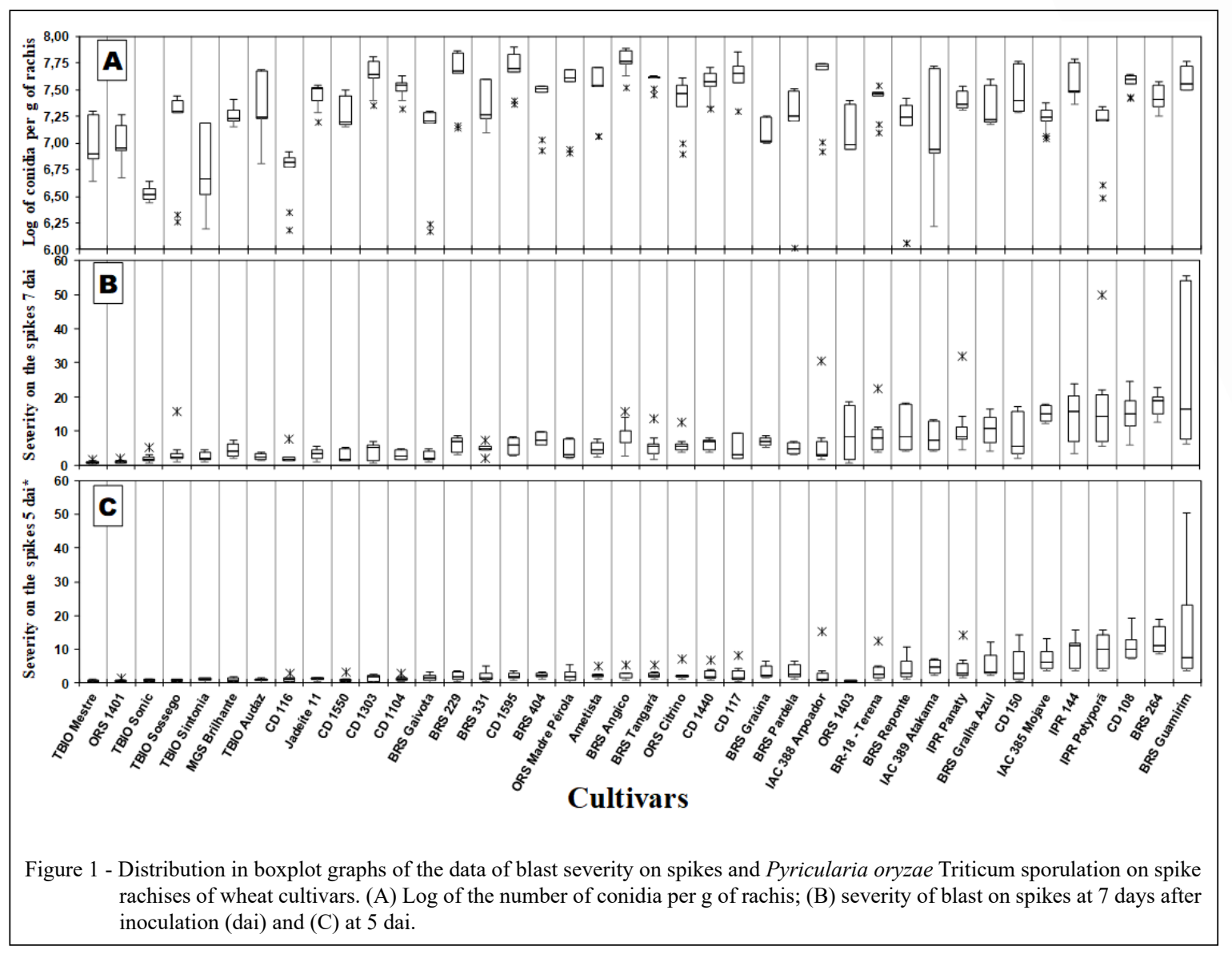

variation and increase the accuracy of the analysis. In fact, adjustments or standardization in each phase of the sample preparation may improving the determination of spores on the tissue evaluated.

In addition, it is important to note that $80 \%$ of the cultivars (20 out 25) classified in the group with the lowest rate sporulation were also classified in the group of least resistance at 7 dai. It is still possible to speculate that the processing of digital images, in a similar way that was done by MACIEL et al. (2013b), would greatly minimize the magnitude of the errors of assessing the symptoms, providing better conditions for the establishment of the correlation between blast severity on the spikes and rate of sporulation of PoT.

Conversely, the finding that the pathogen was able to sporulate on the rachises of all evaluated cultivars corroborates the perception that, among the tested cultivars, there is no complete resistance to the infectious process of PoT in adult plants. This situation differs from that was verified by MACIEL et al. (2014) who reported the absence of infection in seedling infections depending on the combination of the PoT isolate and wheat cultivar used in the inoculations.

\section{CONCLUSION}

The results obtained represent an updated characterization of the reaction to the blast of wheat cultivars of frequent use in Brazil, highlighting that $85 \%, 80 \%$ and $62.5 \%$ of the tested cultivars were classified in groups of greater resistance according to the severity of blast at 5 and 7 dai and sporulation rates of PoT on reachis spikes, respectively.

The finding of lack of correlation between spike blast severity and PoT sporulation rate on the rachises should be considered as an exploratory mark for assessing the reaction of wheat genotypes to the disease based on the sporulation rate of the pathogen on wheat plant tissues and further studies about this topic are encouraged.

\section{ACKNOWLEDGEMENTS}

We are grateful to Conselho Nacional de Desenvolvimento Científico e Tecnológico (CNPq) and Coordenação de Aperfeiçoamento de Pessoal de Nível Superior (CAPES) for providing scholarships for the first (productivity-CNPq- 304795/20178), second (undergraduate-CNPq-PIBIC- 800397/2018-5) and fourth 
(doctoral-CAPES- 88882.427632/2019-01) authors. We also thank EMBRAPA for the financial support, which was made available within the budget of project SEG 12.16.04.009.00.00.

\section{DECLARATION OF CONFLICT OF INTEREST}

The authors declare no conflict of interest.

\section{AUTHORS' CONTRIBUTIONS}

The authors contributed equally to the manuscript.

\section{REFERENCES}

CALLAWAY, E. Devastating wheat fungus appears in Asia for first time. Nature, v.532, p.421-2, 2016. Available from: $<$ https:// www.ncbi.nlm.nih.gov/ pubmed/27121815>. Accessed: Oct. 30, 2020. doi: $10.1038 / 532421$ a

CASTROAGÚDIN, V. L., et al. Pyricularia graminis-tritici, a new Pyricularia species causing wheat blast. Persoonia: Molecular Phylogeny and Evolution of Fungi, v.37, p.199-216, 2016. Available from: <https://www.ncbi.nlm.nih.gov/pmc/articles/ PMC5315288/>. Accessed: Oct. 03, 2020. doi: 10.3767/003158516X692149.

COUCH, B. C.; KOHN, L. M. A multilocus gene genealogy concordant with host preference indicates segregation of a new species, Magnaporthe oryzae, from M. grisea. Mycologia, v.94, p.683-693, 2002. Available from: <https://www.jstor.org/ stable/3761719>. Accessed: Feb. 12, 2021

CRUZ, C. D. Programa GENES: versão Windows, aplicativo computacional em genética e estatística. Viçosa: UFV, 2001. 648p.

CRUZ, M. F. A., et al. Resistência parcial à brusone de genótipos de trigo comum e sintético nos estádios de planta jovem e de planta adulta. Tropical Plant Pathology, v.35, p.24-31, 2010. Available from: <http://www.scielo.br/pdf/tpp/v35n1/a04v35n1. pdf $>$. Accessed: Jul. 19, 2020.

DANELLI, A. L. D. Pyricularia oryzae: virulência de isolados, densidade de conídio no ar e efeito do nitrogênio na susceptibilidade do trigo. 2015. 177f. Tese Doutorado - Programa de Pós-Graduação em Agronomia, Universidade de Passo Fundo. Available from: $<$ https://secure.upf.br/pdf/2015AndersonDaneli.pdf $>$. Accessed: May, 09, 2020

DUVEILLER, E., et al. Wheat blast caused by Maganaporthe grisea: a reality and new challenge for wheat research. In: International Wheat Conference, 8. 2010, St. Petersburg. Abstracts ... St. Petersburg: Vavilov Research Institute of Plant Industry, p.247-248, 2010. Available from: <https://www.cabdirect.org/ cabdirect/abstract/ 20123015893>. Accessed: Jun. 08, 2020.

GOULART, A. C. P., et al. Danos em trigo causados pela infecção de Pyricularia grisea. Summa Phytopathologica, v.33, p.358 363, 2007. Available from: <https://www.scielo.br/pdf/sp/v33n4/ a07v33n4.pdf>. Accessed: Sep. 22, 2020. doi: 10.1590/S010054052007000400007.
KOVALESKI, M., et al. Conidia sporulation of Pyricularia oryzae in segments of wheat plants under six different temperatures. Ciência Rural, v.50, e20190573, 2019. Available from: <https:// doi.org/10.1590/0103-8478cr20190573>. Accessed: Apr. 02, 2021.

LECLERC, M., et al. Assessing the effects of quantitative host resistance on the life-history traits of sporulating parasites with growing lesions. Proceedings of the Royal Society B: Biological Sciences, v.286, p.1-9, 2019. Available from: $<$ http://doi.org/10.1098/ rspb.2019.1244>. Accessed: Aug. 03, 2020. doi :10.1098/rspb. 2019.1244 .

KOHLI, M. M., et al. Pyricularia blast - a threat to wheat cultivation. Czech Journal of Genetics and Plant Breeding, v.47, p.130 134, 2011. Available from: <https://www.agriculturejournals.cz/ publicFiles/48968.pdf>. Accessed: Oct. 15, 2020.

MACIEL, J. L. N., et al. Diagrammatic scale for the assessment of blast on wheat spikes. Summa Phytopathologica, v.39, p.162166, 2013a. Available from: <https: //doi.org/ 10.1590/S010054052013000300003>. Accessed: Jun. 27, 2020.

MACIEL, J. L. N., et al. Estimation of blast severity on rye and triticale spikes by digital image analysis. International Journal of Agronomy, v.2013, p.1-8, 2013b. Available from: <https://www. hindawi.com/journals/ija/2013/878246/>. Accessed: May, 05, 2021.

MACIEL, J. L. N., et al. Resultados da rede de ensaios cooperativos para a resistência à brusone da espiga de trigo (Recorbe), safras 2018 e 2019. Passo Fundo: Embrapa Trigo, 2020. 35p. (Circular técnica, 56).

MACIEL, J. L. N. et al. Population structure and pathotype diversity of the wheat blast pa-thogen Pyricularia oryzae 25 years after its emergence in Brazil. Phytopathology, v.104, n.1, p.95-107, 2014. Available from: <https://www.ncbi.nlm.nih.gov/pubmed/23901831>. Accessed: Oct. 19, 2020. doi: 10.1094/PHYTO-11-12-0294-R.

TEMBO, B., et al. Detection and characterization of fungus (Magnaporthe oryzae pathotype Triticum) causing wheat blast disease on rain-fed grown wheat (Triticum aestivum L.) in Zambia. PloS one, 15(9), e0238724, 2020. Available from: <https://doi. org/10.1371/journal.pone.0238724>. Accessed: May, 05, 2021

TUITE, J. Plant pathological methods: fungi and bacteria Purdue University Lafayette, Indiana, Department of Botany and Plant Pathology, Indiana, U.S., 1969. 239p.

VITTAL, R., et al. Characterization and quantification of fungal colonization of Phakopsora pachyrhizi in soybean genotypes. Phytopathology, v.104, p.86-94, 2014. Available from: <https:// doi.org/10.1094/PHYTO-12-12-0334-R>. Accessed: Mar. 19, 2020. doi: 10.1094/PHYTO-12-12-0334-R.

ZHANG, N., et al. Generic names in Magnaporthales. IMA Fungus, v.7, p.155-159, 2016. Available from: $<$ https://imafungus. biomedcentral.com/articles/10.5598/ imafungus.2016.07.01.09>. Accessed: Jan. 17, 2021.

ZADOKS, J. C., et al. A decimal code for the growth stages of cereals. Weed Research, v.14, n.6, p.415-421, 1974. Available from: <https:// onlinelibrary.wiley.com/doi/abs/10.1111/j.1365-3180.1974.tb01084.x>. Accessed: May, 06, 2020. doi: 10.1111/j.1365-3180.1974.tb01084.x. 